\title{
$\bullet$ \\ Knowledge Regarding Sickle Cell Anaemia among Newly Married Couples: A Qualitative Study
}

IJCRR

Section: Healthcare

Sci. Journal Impact

Factor: $6.1(2018)$

ICV: 90.90 (2018)

(c) (i) (8)

Copyright@IJCRR

\section{Nilima Rakshale ${ }^{1}$, Tessy Sebastian ${ }^{1}$, Kumudini Hatwar ${ }^{2}$, Pooja Bhoyar ${ }^{2}$, Komal Bhute², Pallavi Bhusari², Pooja Jaiswal², Pratiksha Kambdi²}

\author{
'Professor, Smt. Radhikabai Meghe Memorial College of Nursing, Datta Meghe lnstitute of Medical Sciences (Deemed to be Univer- \\ sity), Sawangi (M), Wardha, Maharashtra, India; 'B.Sc. Nursing Student, Smt. Radhikabai Meghe Memorial College of Nursing, Datta \\ Meghe Institute of Medical Sciences (Deemed to be University), Sawangi (M), Wardha, Maharashtra, India.
}

\section{ABSTRACT}

Background: Sickle cell anaemia has a high prevalence in India, especially in the central and western regions like Jharkhand, Bihar, Maharashtra, and Madhya Pradesh and poses a considerable health burden. Dr. Bhosale says that in Maharashtra, most patients are either from Nagpur, Wardha, or the Amravati belt. While the sickle cell mutation was first observed in South India among the tribal groups, the condition afflicts both tribal and non-tribal populations.

Objectives: 1 . To assess the knowledge regarding sickle cell anaemia among newly married couples in a rural area. 2 . To associate knowledge regarding sickle cell anaemia among newly married couples with selected demographic variables.

Materials and Methods: This study was based on a descriptive research design. The population was the newly married couple from the Wardha district. The subject consisted of 50 newly married couples of 1-2 years, in the selected community of Wardha district.

Results: According to information regarding sickle cell anaemia reveals that $86 \%$ of their husband and $64 \%$ of the wife had information about sickle cell anaemia and remaining need not have any information.

Conclusion: This study concluded after analysis that males are having more knowledge than females regarding sickle cell anaemia among newly married couples.

Key Words: Assess, Knowledge, Newly married couple, Sickle anaemia

\section{INTRODUCTION}

Sickle cell anaemia has a high prevalence in India, especially in the central and western regions like Jharkhand, Bihar, Maharashtra, and Madhya Pradesh and poses a considerable health burden. Dr. Bhosale says that in Maharashtra, most patients are either from Nagpur or the Amravati belt. While the sickle cell mutation was first observed in South India among the tribal groups, the condition afflicts both tribal and non-tribal populations. However, the reason behind such a huge number of sickle cell anaemia patients in India is still not known. ${ }^{1}$

Sickle cell disease (SCD) is an autosomal inherited recessive blood disorder that causes red blood cells to become stiff and crescent-shaped. ${ }^{2}$ This leads to several complications including hand-foot syndrome, recurring infections, delayed growth, vision problems, vas occlusion, chronic hemolysis, acute and chronic kidney disease and, eventually, progressive multi-organ damage ${ }^{2-8}$ and stroke ${ }^{9}$. SCD sufferers have also shortened lifespan and poor quality of life ${ }^{4,8-11}$. SCD is one of the most common monogenic diseases in the world, with more than 300,000 babies born with SCD annually ${ }^{5,12}$. It generally affects many African and Asian nations, with the Middle East among the region's most affected ${ }^{2,5,13-15}$.

The chronic nature of sickle cell anaemia requiring lifelong medical attention, expensive symptomatic support therapy, specialized care, associated high morbidity, the reduced life expectancy of the affected, poor attendance at school, the potential risk of developing a drug addiction, particularly to opiates, and the burden on the affected families all indicate that the condition is. ${ }^{17}$

Sickle cell disease is a group of blood disorders that are usually inherited from the parents of an individual. The most

Corresponding Author:

Ms. Nilima Rakshale, Professor, Smt. Radhikabai Meghe Memorial College of Nursing, Datta Meghe Institute of Medical Sciences (Deemed to be University), Sawangi (M), Wardha, Maharashtra, India; E-mail: tushita92@gmail.com

ISSN: 2231-2196 (Print)

Received: 21.06 .2020
ISSN: 0975-5241 (Online)

Revised: 12.08 .2020
Accepted: 16.09 .2020
Published: 06.10 .2020 
prevalent form is called sickle cell anaemia (SCA). It results in an abnormality of the oxygen-carrying haemoglobin protein present in red blood cells. Under certain conditions, this leads to a rigid, sickle-like shape. Problems with sickle cell disease normally start at about 5 to 6 months of age. There may be a number of health problems, such as pain attacks ("sickle-cell crisis"), anaemia, bacterial infections, and stroke. Long-term pain can develop with aging. In the developed world the average life expectancy ranges from 40 to 60 years. Sickle cell disease occurs when a person inherits two defective copies of each parent's haemoglobin gene. There are different subtypes in each haemoglobin gene, depending on the exact mutation. Temperature swings, heat, fatigue, and high altitude can set off an attack. An individual with a single abnormal copy usually has no symptoms and is said to have a sickle-cell trait. These people are called carriers, too. Diagnosis is carried out by a blood test and certain countries screen their children for the disease at birth. Diagnosis during pregnancy also possible. Care for people with sickle cell disease may include vaccination and antibiotic infection prevention, high fluid intake, supplementation with folic acid, and pain medication. Other measures could include blood transfusion and hydroxy-carbamide medication (hydroxyurea). A small proportion of people can be cured by a bone marrow cell transplant.

Sickle cell disease entails elevated risks for both the mother and the baby during pregnancy. A unit that is experienced in caring for women with this condition should look after the female who is affected. Some women with a poor obstetric history or a serious form of sickle cell disease may need a blood transfusion. Regular folic acid, timely infection, and crisis care and increased fluid intake allow most women to get a healthy pregnancy. This study aims at assessing newly married couples' knowledge of sickle cell anaemia.

This study assumed that the newly married couple may have some knowledge of sickle cell anaemia. The hypothesis of this study was, H0: There is no significant association between knowledge scores of newly married couples regarding sickle cell anaemia with a selected demographic variable. H1: There may be a significant association between knowledge scores of newly married couples regarding sickle cell anaemia with a selected demographic variable.

\section{MATERIALS AND METHODS}

This study was based on a descriptive research design. The population was the newly married couple from the Wardha district. The subject consisted of 50 newly married couple 1-2 years in duration, in the selected community of Wardha district. Data was collected by using a self-administered structured questionnaire to obtain information on socio-demographic data and knowledge regarding sickle cell anaemia among study subjects. The levels of knowledge were seen inside 5 categories, poor, average, good, very good, and excellent. Data collection was done manually. Computer data processing was done using SPSS version 21.

\section{INCLUSION CRITERIA}

The newly married couple had a 1-2 year duration of the marriage. Couple those who are available at the time of data collection. Couple those who are willing to participate.

\section{EXCLUSION CRITERIA}

Couple those who are health personnel. Couple those who have suffered and treated for sickle cell anaemia in the past. Couple those who can understand read and write Hindi or Marathi language.

\section{RESULTS}

\section{Organization of findings}

The analysis and interpretation of the observations are given in the following section:

Section A: Distribution of newly married couples with regards to demographic variables.

Section B: Assessment of knowledge regarding sickle cell anaemia among newly married couples.

Section C: Association of knowledge score regarding sickle cell anaemia among newly married couple with selected demographic variables

Section A: Distribution of newly married couples with regards to demographic variables.

Table 1: Percentage-wise distribution of newly married couples according to their demographic characteristics.

$$
\mathrm{n}=\mathbf{5 0}+\mathbf{5 0}
$$

Demographic Variables Husband $(n=50) \quad$ Wife $(n=50)$

Age( in years)

$\begin{array}{lcc}18-23 \text { yrs } & 0(0 \%) & 14(28 \%) \\ 24-29 \text { yrs } & 17(34 \%) & 30(60 \%) \\ 30-35 \text { yrs } & 31(62 \%) & 5(10 \%) \\ 36-45 \text { yrs } & 2(4 \%) & 1(2 \%) \\ \text { Educational Status } & & \\ \text { Primary } & 0(0 \%) & 1(2 \%) \\ \text { Secondary } & 2(4 \%) & 12(24 \%) \\ \text { Higher Secondary } & 27(54 \%) & 20(40 \%) \\ \text { Graduation and above } & 21(42 \%) & 17(34 \%) \\ \text { Religion } & & \\ \text { Hindu } & 16(32 \%) & 16(32 \%)\end{array}$


Table 1: (Continued)

\begin{tabular}{|c|c|c|}
\hline Demographic Variables & Husband(n=50) & Wife $(n=50)$ \\
\hline Muslim & $1(2 \%)$ & $1(2 \%)$ \\
\hline Christian & $1(2 \%)$ & $1(2 \%)$ \\
\hline Buddhist & $32(64 \%)$ & $32(64 \%)$ \\
\hline \multicolumn{3}{|l|}{ Residence } \\
\hline Urban & $\mathrm{o}(\mathrm{o} \%)$ & $\mathrm{o}(\mathrm{o} \%)$ \\
\hline Rural & $50(100 \%)$ & $50(100 \%)$ \\
\hline \multicolumn{3}{|l|}{ Occupation } \\
\hline Farmer & $8(16 \%)$ & $11(22 \%)$ \\
\hline Daily Wages Earner & $17(34 \%)$ & $11(22 \%)$ \\
\hline Service & $13(26 \%)$ & $9(18 \%)$ \\
\hline Housewife & $\mathrm{o}(\mathrm{o} \%)$ & $29(58 \%)$ \\
\hline Self Business & $12(24 \%)$ & $\mathrm{o}(\mathrm{o} \%)$ \\
\hline \multicolumn{3}{|c|}{ Monthly family income(Rs) } \\
\hline 3000-60oo Rs & $8(16 \%)$ & $7(14 \%)$ \\
\hline 6oo1-90oo Rs & $6(12 \%)$ & $8(16 \%)$ \\
\hline 9001-12000 Rs & $22(44 \%)$ & $22(44 \%)$ \\
\hline$>12001$ Rs & $14(28 \%)$ & $13(26 \%)$ \\
\hline \multicolumn{3}{|c|}{ Information regarding sickle cell anaemia } \\
\hline Yes & $43(86 \%)$ & $32(64 \%)$ \\
\hline No & $7(14 \%)$ & $18(36 \%)$ \\
\hline \multicolumn{3}{|l|}{ Source of information } \\
\hline Health Personnel & $26(52 \%)$ & $21(42 \%)$ \\
\hline Media & $11(22 \%)$ & $7(14 \%)$ \\
\hline Relatives & $6(12 \%)$ & $7(14 \%)$ \\
\hline None of the above & $7(14 \%)$ & $15(30 \%)$ \\
\hline \multicolumn{3}{|c|}{ Sickle cell anaemia in family } \\
\hline Yes & $3(6 \%)$ & $6(12 \%)$ \\
\hline No & $47(94 \%)$ & $44(88 \%)$ \\
\hline \multicolumn{3}{|l|}{ Relation with that person } \\
\hline Mother & $1(2 \%)$ & $3(6 \%)$ \\
\hline Daughter & $1(2 \%)$ & $1(2 \%)$ \\
\hline Father & $\mathrm{o}(\mathrm{o} \%)$ & $1(2 \%)$ \\
\hline Sister & $\mathrm{o}(\mathrm{o} \%)$ & $1(2 \%)$ \\
\hline
\end{tabular}

The above table 1 depicts frequency and percentage-wise distribution of newly married couple according to their age in years, educational status, religion, occupational status, monthly family income in Rs, information regarding sickle cell anaemia, source of information, sickle cell anaemia in the family and relation with that person of sickle cell anaemia, etc.

Section B: Assessment of knowledge regarding sickle cell anaemia among newly married couples.
Table 2: Distribution of newly married couple with regards to knowledge regarding sickle cell anaemia in a rural area

\begin{tabular}{lcccc}
\multicolumn{5}{c}{$\mathbf{n = 5 0 + 5 0}$} \\
$\begin{array}{l}\text { Level of } \\
\text { knowledge } \\
\text { score }\end{array}$ & $\begin{array}{c}\text { Score } \\
\text { Range }\end{array}$ & $\begin{array}{c}\text { Percentage } \\
(\%)\end{array}$ & \multicolumn{2}{c}{ Knowledge N (\%) } \\
Husband & Wife \\
Poor & $1-3$ & $0-20 \%$ & $3(6 \%)$ & $1(2 \%)$ \\
Average & $4-6$ & $21-40 \%$ & $8(16 \%)$ & $11(22 \%)$ \\
Good & $7-9$ & $41-60 \%$ & $17(34 \%)$ & $20(40 \%)$ \\
Very Good & $10-12$ & $61-80 \%$ & $20(40 \%)$ & $18(36 \%)$ \\
Excellent & $13-15$ & $81-100 \%$ & $2(4 \%)$ & $0(0 \%)$ \\
Mean \pm SD & & & $8.70 \pm 2.80$ & $8.20 \pm 2.20$ \\
Mean $\%$ & & & $58 \pm 18.72$ & $54.66 \pm 14.69$ \\
Range & & & 3 to 14 & 2 to 12 \\
\hline
\end{tabular}

The above table no 2 shows the frequency and percentagewise distribution of newly married couple according to the level of knowledge regarding sickle cell anaemia. About $6 \%$ of the husband and $2 \%$ of the wife had a poor level of knowledge score, $16 \%$ of the husband and $22 \%$ of the wife had average, $34 \%$ of husband and $40 \%$ of the wife had good, $40 \%$ of husband and $36 \%$ of the wife had very good and $4 \%$ of a husband had an excellent level of knowledge score. The mean knowledge score of the husbands $(8.70 \pm 2.80)$ was better than the wives $(8.20 \pm 2.20)$.

Section C: Association of knowledge score regarding sickle cell anaemia among newly married couples with selected demographic variables.

Table 3: Association of knowledge score regarding sickle cell anaemia among wives concerning the source of information regarding sickle cell anaemia $\mathbf{n}=\mathbf{5 0}+50$

$\begin{array}{lllll}\begin{array}{l}\text { Source of } \\ \text { information }\end{array} & \begin{array}{l}\text { Frequency } \\ \text { of Wife }\end{array} & \begin{array}{l}\text { Mean } \\ \text { knowledge } \\ \text { score }\end{array} & \text { F-value } & \text { p-value } \\ \begin{array}{l}\text { Health Per- } \\ \text { sonnel }\end{array} & 21(42 \%) & 8.66 \pm 1.95 & 6.04 & 0.001 \\ \text { Media } & 7(14 \%) & 8.71 \pm 1.79 & & \text { S, p<0.05 } \\ \text { Relatives } & 7(14 \%) & 9.85 \pm 1.86 & & \\ \text { None of the } & 15(30 \%) & 6.53 \pm 1.95 & & \end{array}$

above

This table shows the association of knowledge scores with a source of information regarding sickle cell anaemia of wife. The Tabulated ' $\mathrm{F}$ ' value was $4.13(\mathrm{df}=3,46)$ which is much less than the Calculated ' $F$ ' i.e. 6.04 at a $5 \%$ level of significance. Also, the calculated ' $p$ ' $=0.001$ which was much less than the acceptable level of significance i.e. ' $p$ ' $=0.05$. Hence it is interpreted that source of information regarding sickle cell anaemia of wife is statistically associated with their knowledge score. Hence H1 is accepted. 
Table 4: Association of knowledge score regarding sickle cell anaemia among husbands to their source of information regarding sickle cell anaemia.

\begin{tabular}{|c|c|c|c|c|}
\hline \multicolumn{5}{|c|}{$\mathrm{n}=\mathbf{5 0}+\mathbf{5 0}$} \\
\hline $\begin{array}{l}\text { Source of infor- } \\
\text { mation }\end{array}$ & $\begin{array}{l}\text { Frequency } \\
\text { of Hus- } \\
\text { band }\end{array}$ & $\begin{array}{l}\text { Mean } \\
\text { knowledge } \\
\text { score }\end{array}$ & $\begin{array}{l}\text { F- } \\
\text { value }\end{array}$ & $\begin{array}{l}\text { p- } \\
\text { value }\end{array}$ \\
\hline Health Personnel & $26(52 \%)$ & $9.84 \pm 2.27$ & 8.49 & 0.0001 \\
\hline Media & $11(22 \%)$ & $6.63 \pm 2.61$ & & $\mathrm{~S}$, \\
\hline Relatives & $6(12 \%)$ & $10.33 \pm 2.65$ & & $\mathrm{p}<0.05$ \\
\hline $\begin{array}{l}\text { None of the } \\
\text { above }\end{array}$ & $7(14 \%)$ & $6.28 \pm 1.60$ & & \\
\hline
\end{tabular}

This table shows the association of knowledge scores with a source of information regarding sickle cell anaemia of husband. The Tabulated 'F' value was $4.13(\mathrm{df}=3,46)$ which is much less than the Calculated ' $F$ ' i.e. 8.49 at a $5 \%$ level of significance. Also, the calculated ' $p$ ' $=0.0001$ which was much less than the acceptable level of significance i.e. ' $p$ ' $=0.05$. Hence it is interpreted that the source of information regarding sickle cell anaemia of husband is statistically associated with their knowledge score. Hence H1 is accepted.

Table 5: Association of knowledge score regarding sickle cell anaemia among husbands concerning their educational status.

\begin{tabular}{lcccc}
\multicolumn{5}{c}{$\mathbf{n = 5 0 + 5 0}$} \\
$\begin{array}{lccc}\text { Educational } \\
\text { Status }\end{array}$ & $\begin{array}{c}\text { Frequency } \\
\text { of Husband }\end{array}$ & $\begin{array}{c}\text { Mean } \\
\text { knowledge } \\
\text { score }\end{array}$ & $\begin{array}{c}\text { F- } \\
\text { value }\end{array}$ & p-value \\
Primary & $\mathrm{o}(\mathrm{o} \%)$ & $\mathrm{O} \pm 0$ & 3.74 & $\begin{array}{c}0.031 \\
\mathrm{~S}, \mathrm{p}<0.05\end{array}$ \\
$\begin{array}{l}\text { Secondary } \\
\text { Higher Sec- }\end{array}$ & $\mathbf{2}(4 \%)$ & $5 \pm 2.82$ & & \\
$\begin{array}{l}\text { ondary } \\
\begin{array}{l}\text { Graduation } \\
\text { and above }\end{array}\end{array}$ & $\mathbf{2 1}(42 \%)$ & $8.22 \pm 2.88$ & & \\
\hline
\end{tabular}

This table shows the association of knowledge scores with the educational status of the wife. The Tabulated ' $F$ ' value was $4.13(\mathrm{df}=3,46)$ which is much less than the Calculated ' $F$ ' i.e. 1.75 at a $5 \%$ level of significance. Also, the calculated ' $p$ ' $=0.17$ which was much less than the acceptable level of significance i.e. ' $p$ ' $=0.05$. Hence it is interpreted that the educational status of wife is statistically associated with their knowledge score. Hence H1 is accepted.
Table 6: Association of knowledge score regarding sickle cell anaemia among husband to their religion $\mathbf{n}=\mathbf{5 0}+50$

\begin{tabular}{lcccc} 
Religion & $\begin{array}{c}\text { Frequency } \\
\text { of Husband }\end{array}$ & $\begin{array}{c}\text { Mean } \\
\text { knowledge } \\
\text { score }\end{array}$ & F-value & p-value \\
Hindu & $16(32 \%)$ & $8.62 \pm 2.47$ & & \\
Muslim & $1(2 \%)$ & $3 \pm 0$ & 1.53 & NS, p>0.05 \\
Christian & $1(2 \%)$ & $10 \pm 0$ & & \\
Buddhist & $32(64 \%)$ & $8.87 \pm 2.89$ & & \\
\hline
\end{tabular}

This table shows the association of knowledge scores with the religion of the husband. The Tabulated ' $F$ ' value was 4.13( $\mathrm{df}=3,46)$ which is much higher than the Calculated ' $\mathrm{F}$ ' i.e. 1.53 at a $5 \%$ level of significance. Also, the calculated ' $p$ ' $=0.21$ which was much higher than the acceptable level of significance i.e. ' $p$ ' $=0.05$. Hence it is interpreted that the religion of husband among married couple is statistically not associated with their knowledge score. Hence $\mathrm{H} 0$ is accepted

Table 7: Association of knowledge score regarding sickle cell anaemia in among husband to their occupational status

$$
\mathrm{n}=\mathbf{5 0}+\mathbf{5 0}
$$

\begin{tabular}{|c|c|c|c|c|}
\hline $\begin{array}{l}\text { Occupational } \\
\text { Status }\end{array}$ & $\begin{array}{l}\text { Frequency } \\
\text { of Husband }\end{array}$ & $\begin{array}{l}\text { Mean } \\
\text { knowledge } \\
\text { score }\end{array}$ & $\begin{array}{l}\text { F- } \\
\text { value }\end{array}$ & p-value \\
\hline Farmer & $8(16 \%)$ & $9.25 \pm 1.98$ & 2.45 & 0.075 \\
\hline $\begin{array}{l}\text { Daily Wages } \\
\text { Earner }\end{array}$ & $17(34 \%)$ & $8.64 \pm 3.29$ & & $\mathrm{NS}, \mathrm{p}<0.05$ \\
\hline Service & $13(26 \%)$ & $9.92 \pm 1.93$ & & \\
\hline Housewife & $\mathrm{o}(\mathrm{o} \%)$ & $\mathrm{O} \pm \mathrm{O}$ & & \\
\hline Self Business & $12(24 \%)$ & $7.08 \pm 2.81$ & & \\
\hline
\end{tabular}

This table shows the association of knowledge scores with the occupational status of the husband. The Tabulated ' $F$ ' value was $4.13(\mathrm{df}=3,46)$ which is much higher than the Calculated ' $F$ ' i.e. 2.45 at a $5 \%$ level of significance. Also, the calculated ' $p$ ' $=0.075$ which was much higher than the acceptable level of significance i.e. 'p' $=0.05$. Hence it is interpreted that the occupational status of the husband is statistically not associated with their knowledge score. Hence H1 is accepted

\section{DISCUSSION}

To assess the knowledge regarding sickle cell anaemia among newly married couples in a rural area was undertaken to assess the knowledge regarding sickle cell anaemia among newly married couples to ascertain the relationship 
with selected socio-demographic variables and to find out the deficit areas. 50 couples were selected by purposive sampling technique. Data were collected from newly married couples (husband \& wives) by questionnaire. Data were analyzed by descriptive and inferential statics and presented through tables and figures. As per objective, it was found that the existing knowledge regarding sickle cell anaemia among newly married couples $86 \%$ (husband) \& $64 \%$ (wives).

Education variables were found to be associated with the knowledge of couples (husband \& wives) none of the other variables was found significantly related to the knowledge of couples. This study is supported to Knowledge, perception, and practices towards sickle cell disease: a community survey among adults in Lubaga division, Kampala Uganda conducted by Sharifu K. Tusuubira that the study results indicate that more effort needs to be done to promote sickle cell awareness in Uganda communities with an emphasis on the inclusion of sickle cell in health education campaigns.

In the present study educational level of husband and source of information, of husband variable found significant with knowledge of married couples, and other variables are not being found significant.

One analysis showed that about $101(28.8 \%)$ had a strong knowledge of SCD and premarital screening (9-5 points out of 9), while the remaining 250 (71.2\%) had poor knowledge of SCD and premarital screening. The median score was 6 (interquartile [IQR] range= 2). A total of $345(98.3 \%)$ participants knew about PMGC, but 153 (43.6\%) did not know the basic studies carried out and were screening for diseases. A total of 330 (94\%) participants were aware that PMGC restricts the spread of inherited blood disorders and 268 (76.4\%) participants were aware that if a member has an inherited blood disorder, families suffer from psychological stress. Analysis of Bivariate showed a significant association $(p=0.043)$ between knowledge level and age group. The age group with the best knowledge was 29-39 years old, with 40 participants out of $112(35.7 \%)$ rating "nice" for knowledge. ${ }^{16}$

One other article showed poor SCD knowledge among the subjects studied. More focus is required on health education through initiatives that facilitate sickle cell education through mass media, school health facilities, and incorporating the subject in the country's primary and secondary schools' physical and health education curriculum. Additionally, the development of multifaceted patient and public health education programs, the intensification of screening for SCD control by heterozygote detection, especially during routine replacements and premarital medical examinations, and the provision of genetic counselling to all sickle cell patients and carriers are vital to the identification and care of at-risk couples. This should strengthen the eager couples' ability to make educated choices, develop communication about their sickle cell status, and be mindful of the dangers of having children with SCD and the implications of these choices. Careful monitoring of policies to ensure effective accessibility of community-wide sickle cell screening and premarital and genetic therapy to achieve the desired decline in new births of children with SCD is of particular importance. ${ }^{18}$

\section{CONCLUSION}

It is found that males are having more knowledge than females regarding sickle cell anaemia among newly married couples. The majority in couples $86 \%$ (husband) and $64 \%$ (wives) knowing sickle cell anaemia. The demographic variable like age, educational status, type of family, religion, occupation, income shows little influence on the knowledge of the newly married couple. All (100\%) of them were residing in rural areas. There is a need to focus on awareness among married women's regarding sickle cell anaemia.

Acknowledgement: We would like to thank the Hon'ble Vice-Chancellor of Datta

Meghe Institute of Medical Sciences (Deemed to be University), Sawangi (M), Dr. Rajiv M Borle for the support. We also like to thank the authors whose works have been cited and included in this review such as, Vojdani A, Thrasher JD, Gail McKeown-Eyssen, and Sheryl Kataoka. We acknowledge the enormous assistance received from the scholar whose article is cited and incorporated in the manuscript references. We do thank the authors/editors/publishers of all those papers, journals and books from which the literature from this article was reviewed and addressed.

Conflict of Interest: The authors declare that there are no conflicts of interest.

\section{Source of Funding: Self}

Ethical Clearance: Institutional Ethics Committee approval was obtained from IEC, Dutta Meghe Institute of Medical Sciences (DU)/IEC/2016-17/6056).

\section{REFERENCES}

1. A. S. Adewoyin, A. E. Alagbe, B. O. Adedokun, and N. T. Idubor, "Attitude and control practices of sickle cell disease among Youth corps members in Benin city, Nigeria," Annals of Ibadan Postgraduate Medicine,2015; 13( 2): 100-107.

2. A. A. Daak, E. Elsamani, E. H. Ali et al., "Sickle cell disease in western Sudan: genetic epidemiology and predictors of knowledge attitude and practices," Tropical Medicine \& International Health, 2016;21(5): 642-653.

3. M. M. Alotaibi, "Sickle cell disease in Saudi Arabia: a challenge or not," Journal of Epidemiology and Global Health, 2017; 7(2): 99-101.

4. F. B. Piel and D. J. Weatherall, "Sickle-cell disease: a call to action," Transactions of the Royal Society of Tropical Medicine and Hygiene, 2015; 109(6): 355-356. 
5. A. Alhwiesh, "An update on sickle cell nephropathy," Saudi Journal of Kidney Diseases and Transplantation, 2014; 25(2): 249-265.

6. A. Aleem, "Renal abnormalities in patients with sickle cell disease: a single-centre report from Saudi Arabia," Saudi Journal of Kidney Diseases and Transplantation, 2008;19(2):194-199.

7. M. G. Sehlo and H. Z. Kamfar, "Depression and quality of life in children with sickle cell disease: the effect of social support," BMC Psychiatry, 2015; 15:1.

8. M. Elsayid, M. J. Al-Shehri, Y. A. Alkulaibi, A. Alanazi, and S. Qureshi, "Frequency distribution of sickle cell anaemia, sickle cell trait and sickle/beta-thalassemia among anaemic patients in Saudi Arabia," Journal of Natural Science, Biology and Medicine, 2015; 6: S85-S88.

9. F. E. Al Jama, T. Gasem, S. Burshaid, J. Rahman, S. A. Al Suleiman, and M. S. Rahman, "Pregnancy outcome in patients with homozygous sickle cell disease in a university hospital, Eastern Saudi Arabia," Archives of Gynecology and Obstetrics, 2009; 280 (5): 793-797.

10. A. E. Ahmed, A. S. Alaskar, A. M. Al-Suliman et al., "Healthrelated quality of life in patients with sickle cell disease in Saudi Arabia," Health and Quality of Life Outcomes, 2015;13(1): article 183.

11. A. E. Ahmed, A. S. Alaskar, D. K. McClish et al., "Saudi SCD patients' symptoms and quality of life relative to the number of ED visits," BMC Emergency Medicine, 2016;16(1).
12. G. R. Serjeant, B. E. Serjeant, K. P. Mason et al., "Voluntary premarital screening to prevent sickle cell disease in Jamaica: does it work?" Journal of Community Genetics, 2017;8(2):133-139.

13. M. A. F. El-Hazmi, A. M. Al-Hazmi, and A. S. Warsy, "Sickle cell disease in Middle East Arab countries," Indian Journal of Medical Research, 2011; 134(11): 597-610.

14. W. Jastaniah, "Epidemiology of sickle cell disease in Saudi Arabia," Annals of Saudi Medicine, 2011; 31(3): 289-293.

15. O. A. Al-Farsi, Y. M. Al-Farsi, I. Gupta, A. Ouhtit, K. S. AlFarsi, and S. Al-Adawi, "A study on knowledge, attitude, and practice towards premarital carrier screening among adults attending primary healthcare centres in a region in Oman," BMC Public Health, 2014;4(1):380, 2014.

16. Heba M. Al-Qattan, Dana F. Amlih, Fatima S. Sirajuddin, Quantifying the Levels of Knowledge, Attitude, and Practice Associated with Sickle Cell Disease and Premarital Genetic Counseling in 350 Saudi Adults. Hindawi, vol. 2019; 1-7.

17. Sickle cell disorder in the African region Current situation and the way forward. WHO Regional Committee for Africa AFR/ RC56/17-2006.

18. Emmanuel A. Abioye-Kuteyi, Olanrewaju Oyegbade, Ibrahim Bello, and Chiddude Osakwe, Sickle cell knowledge, premarital screening and marital decisions among local government workers in Ile-Ife, Nigeria Afr J Prim Health Care Fam Med. 2009;23; 1(1): 022 . 